\title{
Exploring the phyto- and physicochemical evaluation, fluorescence characteristics, and antioxidant activities of Acacia ferruginea Dc: an endangered medicinal plant
}

\author{
M. Jeevitha ${ }^{1 *}$, Pavithra V. Ravi ${ }^{2}$, Vinodhini Subramaniyam² ${ }^{2}$, Moorthi Pichumani ${ }^{2}$ and Shubashini K. Sripathi ${ }^{1}$
}

\begin{abstract}
Background: Herbal plants are potent in curing various ailments of ancient times as they have comparatively lesser side effects. The demands for natural drugs, mostly from plant sources, are increasing over the past few decades. Because of their potent antioxidant activity, Acacia species are used to treat a variety of diseases. One of the species Acacia ferruginea, an endangered medicinal plant, is widely used in the traditional medicine system, and it is considered that standardization would be beneficial. The present study investigates the physicochemical parameters, preliminary phytochemical screening, trace metals by SEM-EDS, and fluorescence properties of various extracts (nonpolar to polar) of leaf and bark parts. Standard spectrophotometric methods (UV-Vis, FT-IR, fluorescence spectroscopy) are employed to analyze the functional groups, and the DPPH and total antioxidant methods are used to assess antioxidant potential.

Results: The ethyl acetate extract of leaves and ethanol extract of the bark are found to be the highest in yield, $16.32 \%$ and $2.54 \%$. Results reveal that the total ash percentage and moisture content are of bark and the watersoluble ash of leaves is higher $(10.3 \pm 0.85,7.6 \pm 0.34,3.22 \pm 0.24 \%)$. The bark polar extract contained more macroelements such as $\mathrm{Na}, \mathrm{K}, \mathrm{Mg}, \mathrm{Ca}$, S, and Cl. Phytochemical analysis reveals the polar extracts of leaves and bark show saponins, flavonoids, steroids, phenolic compounds, and non-polar extracts show mild positive. The total alkaloids, phenolics, and terpenoids $(1.58 \pm 0.08 \% ; 0.56 \pm 0.11 ; 0.75 \pm 0.15)$ are found to be higher in $A$. ferruginea leaves. The FT-IR result shows the presence of alkanes, alkenes, aromatic compounds, aldehydes, phenolics and does not contain any toxic substances since there is no peak observed in the region between 2220 and $2260 \mathrm{~cm}^{-1}$. The in vitro antioxidant activity of the species demonstrated that both the leaf and bark parts have prominent antioxidant properties.

Conclusions: The results obtained from the preliminary standardization of $A$. ferruginea are very helpful in the determination of the quality and purity of the crude drug. The refurbished findings of $A$. ferruginea are promising, and further research is important to identify the bioactive compounds, thereby developing nutritional supplements and medications through therapeutic compound isolation.
\end{abstract}

Keywords: Acacia ferruginea, Medicinal plants, Phytochemicals, Physicochemical analysis, Fluorescence, Spectroscopy, FT-IR, Antioxidant, Endangered

\footnotetext{
*Correspondence: jeevichemistry@gmail.com

${ }^{1}$ Department of Chemistry, Avinashilingam Institute for Home Science

and Higher Education for Women, Tamil Nadu, Coimbatore 641 043, India

Full list of author information is available at the end of the article
}

(c) The Author(s) 2021. Open Access This article is licensed under a Creative Commons Attribution 4.0 International License, which permits use, sharing, adaptation, distribution and reproduction in any medium or format, as long as you give appropriate credit to the original author(s) and the source, provide a link to the Creative Commons licence, and indicate if changes were made. The images or other third party material in this article are included in the article's Creative Commons licence, unless indicated otherwise in a credit line to the material. If material is not included in the article's Creative Commons licence and your intended use is not permitted by statutory regulation or exceeds the permitted use, you will need to obtain permission directly from the copyright holder. To view a copy of this licence, visit http://creativecommons.org/licenses/by/4.0/. 


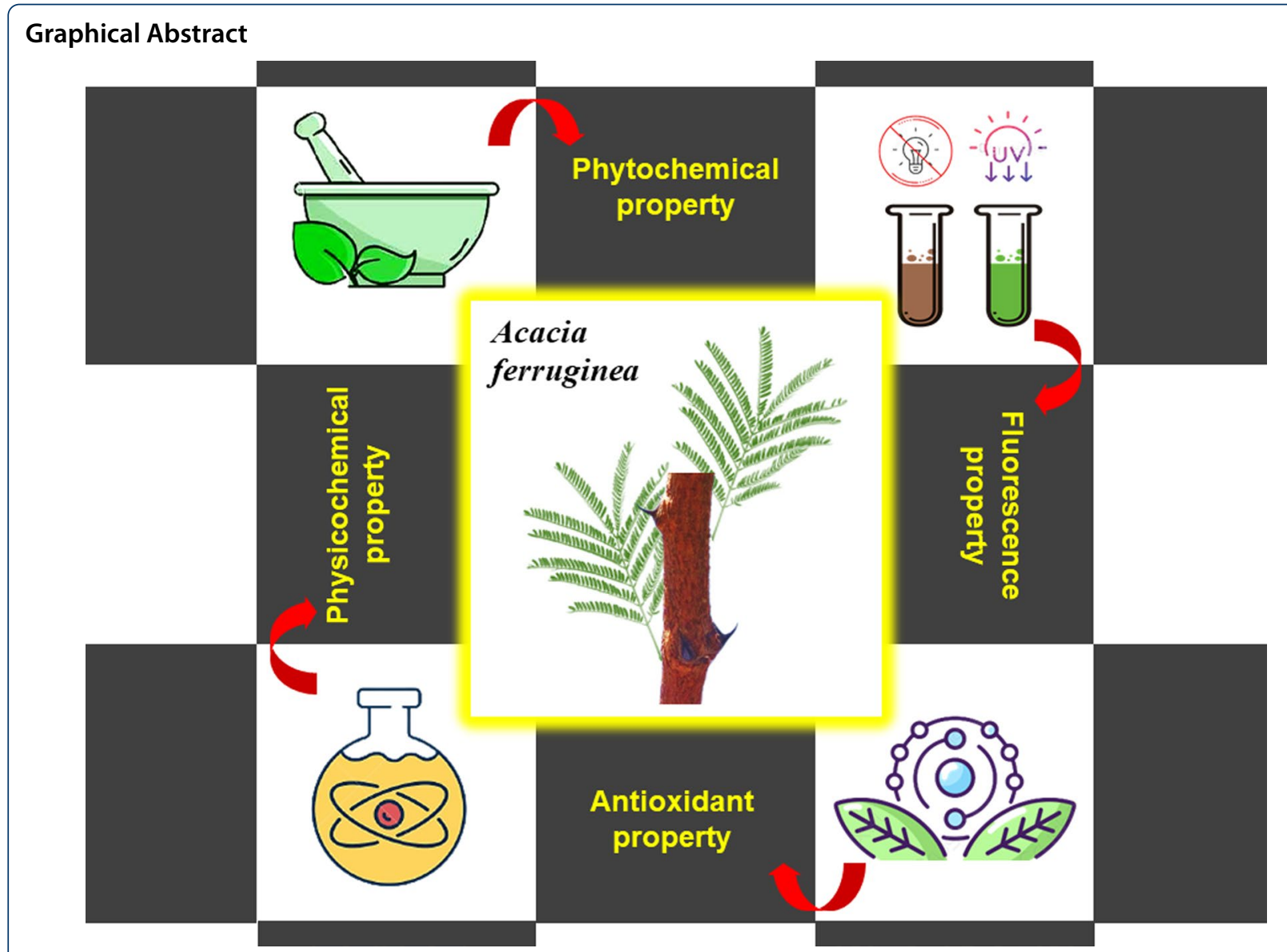

\section{Background}

Medicinal plants are important sources and have been used for thousands of years for curing health conditions, flavoring, preserving food, and preventing diseases, including epidemics. The relationship between man and his quest for medications in nature dates back thousands of years, as evidenced by a variety of sources including written records, conserved locations, and even original plant medicines. Active compounds engendered during secondary metabolism are typically responsible for the biological properties of plant species [1].

In plants, approximately 50,000 metabolites have been discovered, with the total number expected to reach 200,000 [2]. Modern research has grasped its success and has employed numerous natural remedies known to ancient civilizations and utilized in modern pharmacotherapy for millennia. [3]. Traditional medication, primarily derived from plants, has played a critical role in keeping humans disease-free on our planet. It is difficult to pinpoint where these medicines emerged as a treatment option [4]. Despite the overwhelming impact of modern medicine and enormous breakthroughs in synthetic drug synthesis, traditional cures (now referred to as herbal pharmaceuticals/herbal treatments in many publications) are supported, suggested, and encouraged by the World Health Organization (WHO). Since these remedies are affordable, healthful, and trustworthy because they have no substantial adverse repercussions, they are not only popular but also a good way to cure the disease $[4,5]$. Botanical medicines are gaining popularity around the globe, with consumer demand of more than $\$ 72$ billion, especially in developed and developing nations over the last decade; traditional remedies are thought to enable individuals in Western countries to live healthier lives like their forefathers. People spend billions of dollars on home remedies because they believe herbal medicine is a balanced and proper formula for a healthy existence, which has become a hot commodity on the world market $[6,7]$

Acacia species are multipurpose trees distributed worldwide which comprise nearly 1200 species of the Fabaceae family belonging to the tribe Acaciacea. Approximately 152 chemical components have been discovered from the Acacia species during the last seven 
decades. The main factors for their possible biomedical values are the isolated key compounds (flavonoids, terpenoids, and phytosterols, phenolic acids, hydrocarbons, fatty acids, and other substances) accumulated primarily on leaves, stem barks, and pods. Protein and mineral content are abundant in numerous species, especially in the leaves, twigs, and pods [8, 9]. Acacia species have been extensively investigated because of their widespread ecological amplitude, dietary, and beneficial properties [10].

One of the species, Acacia ferruginea, belongs to the Mimosaceae family, a unique natural source widely used in the traditional systems of medicine to treat various ailments. Irritable bowel syndrome, leprosy, and hemorrhage can be traditionally treated by the bark of $A$. ferruginea as it has higher anti-ulcerogenic and antioxidant activities [11-13]. According to published literature, A. ferruginea, an effective Ayurvedic medicine, is used to cure "Vata" and "Kapha" illnesses. The leaf paste is applied externally to cure burns and scalds, while the pod decoction is used as an astringent and demulcent [14]. It has the potential to grow into a tree or a large shrub and can flourish in a variety of conditions, including tropical, subtropical, warm, and cool temperate zones [15]. Acacia leaves are either real leaves or phyllodes, and flowering (brilliant yellow to cream) occurs in late winter, early spring, or early summer [16]. Seeds are edible and are frequently crushed into flour, and gum flows from the stems and branches due to environmental conditions or stress $[17,18]$. A. ferruginea leaves and bark possess antiinflammatory, larvicidal, anticancer, anti-hemolytic, antidiabetic, and anti-hemorrhoidal properties [19-23]. The quest for novel natural medications is now underway. The development of novel herbal medications is becoming more difficult owing to several challenges, including a lack of understanding of the most active family, genus, and species, required for a thorough investigation [9].

Adulteration and replacement constitute a significant issue in an enterprise that jeopardizes the reputation of the herbal medicine system, resulting from a lack of precise information, misidentification, and personal benefit [24]. To reform this unconstitutional act and enhance customer protection and poor medication handling, physicochemical parameters must be evaluated. From raw ingredients to final goods, the World Health Organization has established many criteria for the standardization of herbal products like quality, safety, and effectiveness of herbal medicines and quantitative norms (such as ash values, extractive values, and volatile matter) $[4,25]$. The chromatographic and spectral fingerprints (UV-visible, FT-IR, fluorescence spectroscopy) of herbal medicines may be used to solve the issue of quality control of herbal medicines as well as offering detailed insights into the molecular properties and quantification of photo components from plant products. Chemical fingerprints collected by chromatographic procedures are highly recommended for establishing the authenticity of traditional medicinal [26, 27]. It necessitates a wellbalanced blend of contemporary analytical methods and traditional knowledge. Stability testing studies are performed to assess the consistency of herbal drugs, which are impacted by various factors such as temperature, humidity, heat, oxygen, moisture, microbial contamination, and trace metal contamination. As a result, studies involving different forms of measurement such as chemical, physical, microbiological, spectral, chromatographic, and therapeutic studies may be useful to investigate opulence [28].

The South African Act on Alien and Invasive Species Regulations classifies Acacia species as an invasive plant (Category 2) [29], and A. ferruginea is red-listed under vulnerable category (updated red list-2015) by "The International Union for Conservation of Nature (IUCN)", a foremost expert on environmental issues that take steps to protect it via several significant international environmental agreements (IUCN conferences, etc.) [30].

The present investigation is beneficial to conserve $A$. ferruginea as it comes under endangered plant species due to overexploitation and environmental conditions. Since there has been no significant scientific evidence on the pharmacological potential and medicinal uses of this genus, the current study is conducted to resolve this lacuna by phytochemical and physicochemical (qualitative and quantitative) assessments.

\section{Methods \\ Chemicals and reagents}

In the present study, all the chemicals (hexane, ethanol, ethyl acetate, millipore water, conc. $\mathrm{H}_{2} \mathrm{SO}_{4}$, conc. $\mathrm{HNO}_{3}$, conc. $\mathrm{HCl}$, picric acid, Ferric chloride, $\alpha$-naphthol, $\mathrm{NaOH}$, sodium acetate, acetic acid, pet ether, chloroform, diethyl ether, acetone, methanol, lead acetate, ammonia, distilled water, DPPH, DMSO, sodium phosphate, ammonium molybdate, ascorbic acid, acetic anhydride, magnesium chips) are purchased from Ranbaxy/HI-MEDIA and are of analytical grade used without purifying further.

\section{Sample collection and preparation of the samples}

The leaves and bark of Acacia ferruginea are collected from the village Nalligoundanpalayam (11012'19.2" N 77017'55.3" E), Avinashi, Tamil Nadu state, India. The plant is authenticated by the Botanical Survey of India, Coimbatore, Tamil Nadu, India (BSI/SRC/5/23/2018/ Tech/2080). The pre-cleaned leaves and bark are dried under shade and pulverized for extraction. 


\section{Extraction}

The dried powder samples of $A$. ferruginea (170 g) are sequentially extracted with solvents with increasing polarities (hexane, ethyl acetate, ethanol, 90\% ethanol, and distilled water (each $1200 \mathrm{~mL}$ )) using a Soxhlet extractor. Solvent traces are removed by drying and are concentrated by simple distillation. The crude extracts are further dried using a rotary evaporator, and aqueous extracts are concentrated by lyophilization (Christ Alpha 1-2 LD plus) and stored at $4^{0} \mathrm{C}$ for further analysis.

\section{Physicochemical studies}

The fresh plant (leaves and bark) powder is used to determine the physicochemical behavior according to methods described in Indian pharmacopeia.

The $\mathrm{pH}$ of different solutions of bark and leaves (1\% w / v and $10 \% \mathrm{w} / \mathrm{v}$ ) of $A$. ferruginea material is measured using a Hanna $\mathrm{pH}$ meter [31]. Ash values (total, water soluble, and acid insoluble) are determined by Thiex et al. [32]. Dry matter, moisture content (LOD) [33], foreign matter [34], solubility, water-soluble and alcohol-soluble extractive values [35], fluorescence studies [36] are also determined. All tests are carried out in triplicate, with the findings expressed as mean and standard deviation, and the details are given in Additional file 1: SI-M1.

\section{Metal content analysis}

The polar and non-polar extracts of $A$. ferruginea are subjected to elemental analysis by adhering the extract to adhesive carbon tape, which is subsequently placed on aluminum specimen stubs and sputtered with a gold sputter coater. The samples are then analyzed using a TESCAN MIRA 3 Scanning Electron Microscope with a magnification of $30 \mathrm{kV}$ and an accelerating voltage of $200 \mathrm{~V}$ to $30 \mathrm{kV}[25,37]$.

\section{Qualitative phytochemical studies}

Qualitative phytochemical analyses for all of the extracts are done by the standard procedures [38]. The extracts are tested for alkaloids, tannins, phenols, flavonoids, steroids, saponins (Additional file 1: SI-M2).

\section{Quantitative studies}

The total terpenoids, alkaloids, and phenolics are quantified from $A$. ferruginea leaves and bark by standard methods [39].

\section{Quantification of phenolic compounds}

At room temperature, $10 \mathrm{~g}$ of the plant sample is extracted several times with $80 \%$ aq. methanol $(100 \mathrm{~mL})$. Whatman filter paper No. 42 is used to filter the entire solution $(125 \mathrm{~mm})$. Then, the filtrate is moved to a crucible, dried over a water bath, and weighed to a constant weight [39].

\section{Quantification of alkaloids}

To the plant sample $(5 \mathrm{~g})$ is added, and $10 \%$ acetic acid in ethanol $(200 \mathrm{~mL})$ is added and left to stand $(4 \mathrm{~h})$. Then, it is filtered and concentrated for a quarter of an hour in a water bath. Drop by drop ammonium hydroxide is applied until the precipitation is complete [39]. The precipitate is cleaned with ammonium hydroxide, dried, and weighed, and the following calculations are made:

$$
\begin{gathered}
\text { \%Alkaloid }=W_{a} / W_{b} \times 100 \\
W_{a} \text {-weight of alkaloid; } W_{s} \text { - weight of sample. }
\end{gathered}
$$

\section{Quantification of terpenoids}

The dried plant extract $\left(100 \mathrm{mg}\left(W_{a}\right)\right)$ is immersed in $9 \mathrm{~mL}$ ethanol for $24 \mathrm{~h}$. Then, it is extracted with petroleum ether $(10 \mathrm{~mL})$ using a separating funnel. The ether extract is separated, into pre-weighed beakers $\left(W_{b}\right)$ and allowed to dry completely [39]. After ether is evaporated, the yield (\%) of total terpenoid content is estimated using the following formula

$$
\text { \%Terpenoid }=W_{a}-W_{b} / W_{a} \times 100
$$

\section{Antioxidant activity \\ Total antioxidant activity (TAA)}

Sample preparation The plant sample $(10 \mathrm{mg})$ is dissolved in $1 \mathrm{~mL}$ DMSO solution and incubated $\left(400^{\circ} \mathrm{C}\right)$ for $24 \mathrm{~h}$ in a shaking incubator (100-120 rpm).

Phatak and Hendre's [40] procedure, with minor modifications, is used to validate total antioxidant activity employing the phosphomolybdenum method. The sample $(0.5 \mathrm{~mL})$ is diluted with the reaction mixture $(0.5 \mathrm{~mL}$ of $28 \mathrm{mM}$ sodium phosphate, $0.6 \mathrm{M} \mathrm{H}_{2} \mathrm{SO}_{4}$, and $4 \mathrm{mM}$ ammonium molybdate reagent solution) and incubated $\left(500{ }^{\circ} \mathrm{C}\right.$; $90 \mathrm{~min}$ ) with a blank tube (without sample). The tubes are sterilized after incubation, and the absorbance is measured at $695 \mathrm{~nm}$ using a UV-visible spectrophotometer (Shimadzu, 1601). TAA ( $\mathrm{mg} / \mathrm{g})$ is measured using ascorbic acid as the standard.

\section{DPPH radical scavenging assay}

The DPPH radical scavenging activity of the different extracts is assessed based on the method given by Chaves et al. [41] The diluted test solutions $(25-200 \mu \mathrm{g} / \mathrm{mL})$ of each extract are added to $0.3 \mathrm{mM} \mathrm{DPPH}$ in methanol solution to reach the final volume of $2 \mathrm{~mL}$. An equal volume of DPPH and methanol served as a blank. After 30 min of incubation at room temperature, the resultant 
solutions appeared yellow rather than purple color. The colorimetric absorbance is fixed at $520 \mathrm{~nm}$, and the percentage of inhibition is calculated using the formula below.

$$
\text { Inhibition } \%=A_{i}-A_{i i} / A_{i} \times 100
$$

$A_{i}$-standard absorbance control; $A_{i i}$-absorbance for extracts.

\section{Spectral fingerprinting \\ UV}

The extracts $(2 \mathrm{~mL} / 1000 \mathrm{ppm})$ are dissolved in their respective solvents, and the UV-Vis spectra are recorded in a double-beam UV spectrophotometer (Systronics U-2701) in the wavelength range of $200-800 \mathrm{~nm}$. A shift reagent $(\mathrm{NaOEt})$ is added to the polar extracts to observe the shift.

\section{$F T-I R$}

FT-IR spectral measurements are recorded in PerkinElmer FTIR00585 spectrophotometer in the range $4000-800 \mathrm{~cm}^{-1}$.

\section{Fluorescence measurements}

The fluorescence (excitation/emission) spectra of $A$. ferruginea extracts are measured using a fluorescence spectrophotometer (Agilent technologies, G9800A) with a wavelength range of 190-1100 nm. Absorption and fluorescence measurements are taken for the extract solution $(2 \mathrm{~mL} / 1000 \mathrm{ppm})$ using quartz cuvettes (path length: $1 \mathrm{~cm})$ at room temperature.

\section{Results}

\section{Extractive values}

In leaves and bark, significant differences in extraction yields are observed for methanol and other solvents. The ethyl acetate extract of leaves and ethanol extract of the bark are observed to be the highest in yield, $16.32 \%$ and $2.54 \%$, followed by ethanol extract of leaves $(8.26 \%)$, respectively, which may be because extractable bioactive components like carbohydrates and proteins are more soluble in ethanol than in the non-polar solvent hexane. The extractive values of $A$. ferruginea bark and leaves are given in Table 1.

\section{Physicochemical evaluation of $A$. ferruginea bark and leaves}

The results of total ash, acid-soluble and insoluble ash, water-soluble and insoluble ash, dry matter, and moisture content of bark and leaves of $A$. ferruginea are given in Tables 2 and 3, respectively. The results reveal that the total ash percentage and moisture content of bark are higher $(10.3 \pm 0.85,7.6 \pm 0.34)$. The total ash of bark $(10.32 \%)$ is found to be more significant than that of leaves $(8.84 \%)$, whereas the water-soluble ash of leaves is higher $(3.22 \pm 0.24 \%)$ than bark which may be due to the presence of a high level of biological residue. The $\mathrm{pH}$ of the bark is found to be higher compared to leaves.

The hexane extract of both bark and leaves is completely soluble in chloroform, and slight miscibility in ethanol is noted for aqueous extract. Ethyl acetate extract of leaves shows complete solubility in ethanol and less solubility in chloroform, acetone, and water. The solubility profile of bark and leaf extracts of A. ferruginea is given in Additional file 1: Table SI-T2.

The bark and leaf powder of the A. ferruginea extracted in various chemical reagents are observed under UV light $(245 \mathrm{~nm})$ and ordinary visible light and recorded in Additional file 1: Table SI-T3, T4. The bark powder of A. ferruginea showed olive green color under UV light and orange under visible light when treated with conc. $\mathrm{HNO}_{3}$. The bark remained colorless under UV and visible light with many solvents. The fluorescent green color is observed

Table 1 Extractive values of A. ferruginea bark and leaf extracts

\begin{tabular}{|c|c|c|c|c|}
\hline S. no & Extracts & Sample name & Solvent & Percentage (\%) \\
\hline 1 & A. ferruginea Bark Hexane & ACFE-B-H & Hexane & 0.33 \\
\hline 2 & A. ferruginea Bark Ethyl acetate & ACFE-B-EA & Ethyl Acetate & 1.59 \\
\hline 3 & A. ferruginea Bark Ethanol & ACFE-B-E & Ethanol & 2.54 \\
\hline 4 & A. ferruginea Bark Hydroethanol & ACFE-B-HE & Hydroethanol (90\%) & 0.23 \\
\hline 5 & A. ferruginea Bark Aqueous & ACFE-B-Aq & Distilled water & 1.67 \\
\hline 6 & A. ferruginea Leaf Hexane & ACFE-L-H & Hexane & 4.32 \\
\hline 7 & A. ferruginea Leaf Ethyl acetate & ACFE-L-EA & Ethyl Acetate & 16.32 \\
\hline 8 & A. ferruginea Leaf Ethanol & ACFE-L-E & Ethanol & 8.26 \\
\hline 9 & A. ferruginea Leaf Hydroethanol & ACFE-L-HE & Hydroethanol (90\%) & 1.26 \\
\hline 10 & A. ferruginea Bark Aqueous & ACFE-L-Aq & Distilled water & 2.35 \\
\hline
\end{tabular}


Table 2 Physicochemical Analysis of Acacia ferruginea bark

\begin{tabular}{|c|c|c|c|c|c|c|}
\hline S. no & Test & $\begin{array}{l}\text { Weight of the } \\
\text { sample taken (g) }\end{array}$ & Initial color & Final color & Temperature ${ }^{\circ} \mathrm{C}$ & $\%$ Value \\
\hline \multirow[t]{2}{*}{1} & $\mathrm{pH} 1 \%$ w/v solution & 1.0 & - & - & $26.9 \pm 0.08$ & $7.2 \pm 0.05$ \\
\hline & $\mathrm{pH} 10 \% \mathrm{w} / \mathrm{v}$ solution & 10.0 & - & - & $28.6 \pm 0.33$ & $6.4 \pm 0.0$ \\
\hline 2 & Total ash content & 2.0 & Brown & White & $0-600,16 \mathrm{~h}$ & $10.3 \pm 0.85$ \\
\hline 3 & Acid-insoluble ash & 2.0 & White & Buff color & $100,5 \mathrm{~min}$ & $1.36 \pm 0.087$ \\
\hline 4 & Water-soluble ash & 2.0 & White & Cloudy white & $100,5 \mathrm{~min}$ & $1.74 \pm 0.013$ \\
\hline 5 & Dry content & 2.0 & Brown & Brown & $105,12 \mathrm{~h}$ & $92.4 \pm 0.35$ \\
\hline 6 & $\begin{array}{l}\text { Moisture content } \\
\text { (Loss on drying) }\end{array}$ & 2.0 & Brown & Brown & $105,12 \mathrm{~h}$ & $7.6 \pm 0.34$ \\
\hline 7 & Foreign matter & 100 & - & - & - & $0.75 \pm 0.21$ \\
\hline 8 & Water-soluble extractive & 5 & - & - & - & $9.45 \pm 0.50$ \\
\hline 9 & Alcohol-soluble extractive & 5 & - & - & - & $12.26 \pm 0.89$ \\
\hline
\end{tabular}

Values are expressed in Mean \pm SD where $n=3$

Table 3 Physicochemical analysis of A. ferruginea leaves

\begin{tabular}{|c|c|c|c|c|c|c|}
\hline S. no & Test & $\begin{array}{l}\text { Weight of the } \\
\text { sample taken }(\mathrm{g})\end{array}$ & Initial color & Final color & Temperature ${ }^{\circ} \mathrm{C}$ & $\%$ Value \\
\hline \multirow[t]{2}{*}{1} & $\mathrm{pH} 1 \%$ w/v solution & 1.0 & - & - & $27 \pm 0.163$ & $6.33 \pm 0.047$ \\
\hline & $\mathrm{pH} 10 \%$ w/v solution & 10.0 & - & - & $29 \pm 0.535$ & $5.8 \pm 0.00$ \\
\hline 2 & Total ash & 2.0 & Green & White & $0-500,16 \mathrm{~h}$ & $8.8 \pm 0.30$ \\
\hline 3 & Acid-insoluble ash & 2.0 & White & White & $100,5 \mathrm{~min}$ & $1.22 \pm 0.13$ \\
\hline 4 & Water-soluble ash & 2.0 & White & White & $100,5 \mathrm{~min}$ & $3.22 \pm 0.24$ \\
\hline 5 & Dry content & 2.0 & Green & Pale green & $105,12 \mathrm{~h}$ & $95.8 \pm 0.85$ \\
\hline 6 & $\begin{array}{l}\text { Moisture content } \\
\text { (Loss on drying) }\end{array}$ & 2.0 & Green & Pale green & $105,12 \mathrm{~h}$ & $4.2 \pm 0.85$ \\
\hline 7 & Foreign matter & 100 & - & - & - & $0.35 \pm 0.11$ \\
\hline 8 & Water-soluble extractive value & 5 & - & - & - & $18.11 \pm 0.43$ \\
\hline 9 & Alcohol-soluble extractive value & 5 & - & - & - & $24.26 \pm 0.66$ \\
\hline
\end{tabular}

Values are expressed in Mean \pm SD where $n=3$

under UV light when the leaf powder is treated with $\mathrm{FeCl}_{3}$. On treatment with $\mathrm{FeCl}_{3}$, leaf powder turned to a fluorescent green color under UV light which may be attributed to the presence of phenolic rings $(-\mathrm{OH})$. Both the leaf and bark powder showed characteristic coloration, viz. pale green, pale brown, and dark in treatment with various chemical reagents under UV and visible light.

\section{Metal content analysis}

Identification of inorganic minerals of leaf and bark extracts of $A$. ferruginea by EDS indicated that the bark polar extract contained more macro-elements such as $\mathrm{Na}, \mathrm{K}, \mathrm{Mg}, \mathrm{Ca}, \mathrm{S}$, and $\mathrm{Cl}$. All extracts except bark hexane extract show the presence of $\mathrm{Al}$, and there is no trace of toxic metals in any of the samples (Table 4). Figure 1 represents the elemental analysis of $A$. ferruginea extracts, and the corresponding values are given in Table 4.

\section{Phytochemical screening}

The polar extracts of leaves and bark show saponins, flavonoids, steroids, phenolic compounds, and non-polar extracts show mild positive. Ethyl acetate extract of the bark and leaves strongly shows the presence of alkaloids, flavonoids, steroids, terpenoids, and a trace amount of saponins (Table 5).

\section{Quantification studies}

The results given in Table 6 show that the total alkaloids, phenolics, and terpenoids of $A$. ferruginea leaves are found to be higher $(1.58 \pm 0.08 \% ; 0.56 \pm 0.11 ; 0.75 \pm 0.15)$. Quantification results show the following order. 
Table 4 Metal content analysis of hexane and hydroethanol extracts of $A$. ferruginea bark and leaves

\begin{tabular}{|c|c|c|c|c|}
\hline \multirow[t]{2}{*}{ Minerals } & \multicolumn{4}{|l|}{ Weight \% } \\
\hline & ACFE-B-H & ACFE-B-HE & ACFE-L-H & ACFE-L-HE \\
\hline Al & - & 0.57 & 0.42 & 0.48 \\
\hline $\mathrm{Au}$ & - & 1.47 & 1.05 & 0.78 \\
\hline$C$ & 80.16 & 45.14 & 77.40 & 61.03 \\
\hline $\mathrm{Ca}$ & - & 1.74 & - & - \\
\hline $\mathrm{Cl}$ & 0.39 & 2.20 & - & - \\
\hline K & - & 2.99 & - & - \\
\hline $\mathrm{Mg}$ & - & 1.12 & - & - \\
\hline Mo & 1.81 & - & - & - \\
\hline $\mathrm{Na}$ & - & 1.07 & - & - \\
\hline $\mathrm{O}$ & 17.64 & 42.09 & 20.84 & 27.07 \\
\hline S & - & 0.60 & - & - \\
\hline $\mathrm{Si}$ & 0.39 & 1.01 & 0.29 & - \\
\hline $\mathrm{Zn}$ & - & - & - & 10.64 \\
\hline
\end{tabular}

A. ferruginea leaves: Total Alkaloids > Total Terpenoids $>$ Total Phenolics.

A. ferruginea bark: Total Terpenoids $>$ Total Phenolics > Total Alkaloids.

\section{Spectral fingerprinting}

\section{UV}

The UV profile shows the peaks at 230, 240, 235, 244, and $238 \mathrm{~nm}$ with the absorption of 1.87, 2.29, 1.87, 1.8, and $1.5 \mathrm{~nm}$ for bark extracts, respectively (Additional file 1: SI-T5, Figs. 2, 3).

\section{FT-IR}

The FT-IR peak values and functional groups of $A$. ferruginea leaves and bark extracts are represented in Additional file 1: SI-T6, SI-T7, and the corresponding FT-IR spectrum profile is shown in Figs. 4, 5. The FT-IR gave a broad peak around $3200 \mathrm{~cm}^{-1}$ for all polar extracts, indicating $\mathrm{O}-\mathrm{H}$ stretching. The strong peak is observed at 1724.36 and $1249.87 \mathrm{~cm}^{-1}$, indicating $\mathrm{C}=\mathrm{O}$ stretching for leaf hexane extract. The stretching band at $1269.16 \mathrm{~cm}^{-1}$ attributes to $\mathrm{C}=\mathrm{O}$ stretching (alkyl/aryl ether) bending vibrations, the peak around $1396.46 \mathrm{~cm}^{-1}$ and $1045.42 \mathrm{~cm}^{-1}$ indicates the presence of $\mathrm{C}-\mathrm{H}$ bending and stretching, and $\mathrm{C}-\mathrm{C}$ bending indicated the presence of alkenes and aromatic compounds, respectively.

\section{Fluorescence spectroscopy}

All fluorescence spectra are stimulated at different wavelengths based on the identification. The strongest
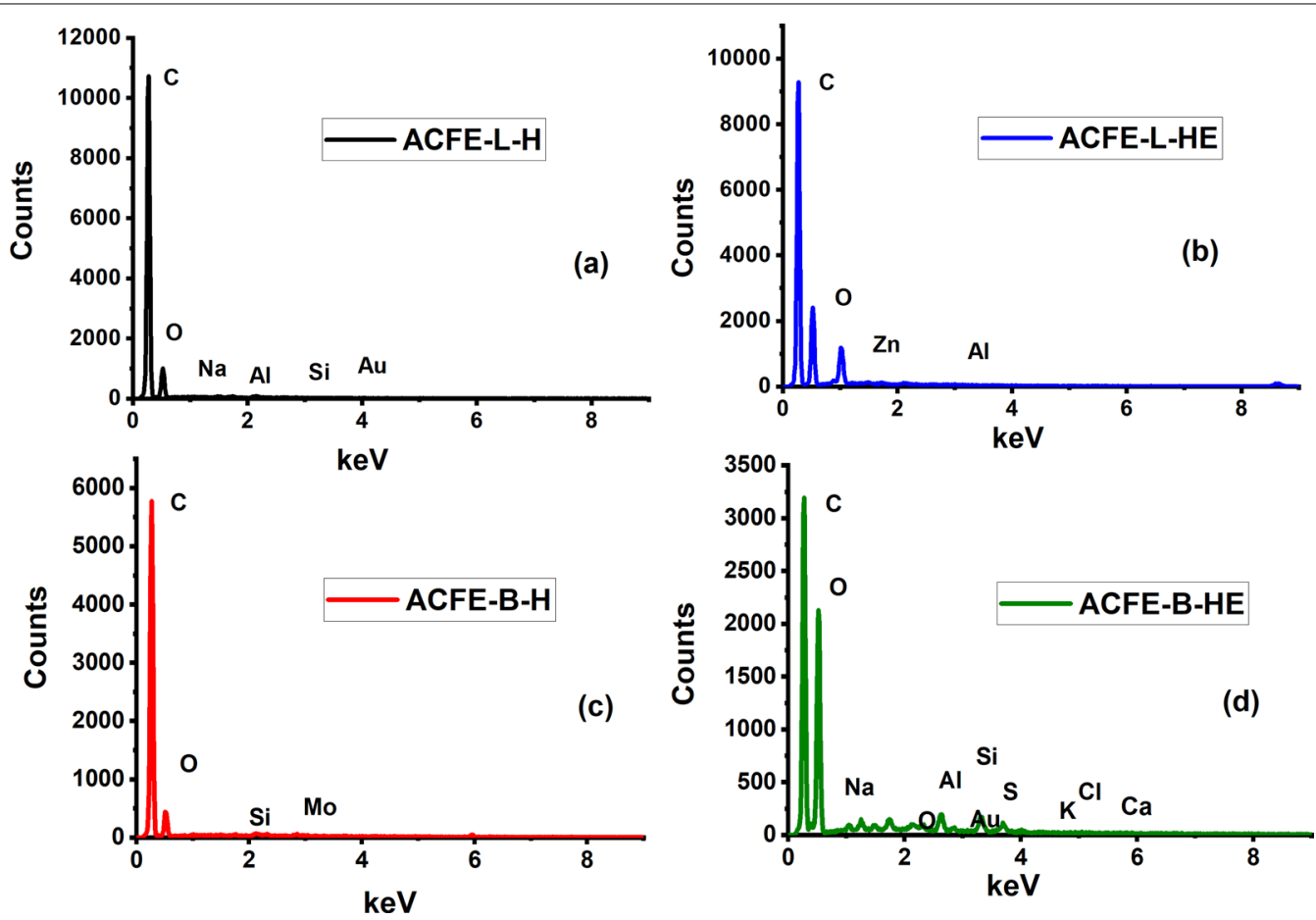

Fig. 1 Energy-dispersive X-ray spectroscopy (EDS) spectra of A. ferruginea leaf and bark extracts a ACFE-L-H, b ACFE-L-HE, c ACFE-B-H, d ACFE-B-HE. EDS Specifications: Magnification-30 kV; field of view-6.4 mm at WD analytical $10 \mathrm{~mm}, 20 \mathrm{~mm}$ at WD $30 \mathrm{~mm}$; accelerating voltage $200 \mathrm{~V}$ to $30 \mathrm{kV}$; probe current-2 pA to $200 \mathrm{nA}$ 
Table 5 Results of phytochemical screening of leaf and bark extracts of A. ferruginea

\begin{tabular}{|c|c|c|c|c|c|c|c|c|}
\hline Sample name & Hager's test & $\mathrm{NaOH}$ & Shinoda & Ferric chloride & Salkowski test & Molisch test & $\begin{array}{l}\text { Liebermann's } \\
\text { test }\end{array}$ & Foam test \\
\hline ACFE-B-H & + & - & - & - & ++ & - & + & - \\
\hline ACFE-B-EA & +++ & + & ++ & ++ & ++ & - & ++ & - \\
\hline ACFE-B-E & ++ & + & - & +++ & ++ & - & - & - \\
\hline ACFE-B-HE & - & - & - & ++ & - & - & - & + \\
\hline ACFE-B-Aq & - & + & + & ++ & - & + & - & + \\
\hline ACFE-L-H & - & - & - & - & + & - & - & - \\
\hline ACFE-L-EA & ++ & + & + & +++ & + & - & + & ++ \\
\hline ACFE-L-E & + & + & +++ & ++ & ++ & - & ++ & ++ \\
\hline ACFE-L-HE & + & ++ & + & ++ & +++ & - & ++ & ++ \\
\hline ACFE-L-Aq & + & ++ & ++ & ++ & + & - & ++ & +++ \\
\hline
\end{tabular}

+++ very strong, ++ trong, + mild,- nil

Table 6 Result of quantification studies-A. ferruginea leaves and bark

\begin{tabular}{llll}
\hline S. no & Test parameters & \multicolumn{2}{l}{ Results (ACFE) } \\
\cline { 3 - 4 } & & Leaves (\%) & Bark (\%) \\
\hline 1 & Total alkaloids & $1.58 \pm 0.08$ & $0.11 \pm 0.03$ \\
2 & Total phenolics & $0.56 \pm 0.11$ & $0.17 \pm 0.06$ \\
3 & Total terpenoids & $0.75 \pm 0.15$ & $0.54 \pm 0.16$ \\
\hline
\end{tabular}

emission intensity is detected for ACFE-B-H extract at the wavelength $791 \mathrm{~nm}$ when excited at $392 \mathrm{~nm}$. No redshift is observed in leaf extracts (ACFE-L-H, ACFE-L-E, ACFE-L-EA, ACFE-L-HE), and the emission wavelength remains the same at increasing emission intensity except for aqueous extract. Fluorescence spectra obtained from Acacia leaf and bark extracts are documented in Additional file 1: SI-T8.

Figures 6 and 7 show emission and excitation spectra of leaf and bark extracts in different solvents, respectively.

\section{Total antioxidant activity (TAA) and DPPH assay}

The propensity for phosphomolybdenum reduction in different sample extracts is in the range of: ACFE-B-Aq $>$ ACFE-B-EA $>$ ACFE-L-E $>$ ACFE-L$\mathrm{EA}>\mathrm{ACFE}-\mathrm{L}-\mathrm{Aq}>\mathrm{ACFE}-\mathrm{B}-\mathrm{E}>\mathrm{ACFE}-\mathrm{B}-\mathrm{H}>\mathrm{ACFE}-\mathrm{L}-$ $\mathrm{HE}>\mathrm{ACFE}-\mathrm{L}-\mathrm{H}>\mathrm{ACFE}-\mathrm{B}-\mathrm{HE}$, and the respective values are found to be $608>559>531>522>464>385>372>24$ $8>218>198 \mathrm{mg} / \mathrm{g}$ of total antioxidant activity.

The results reveal that both A. ferruginea leaves and polar bark extracts exhibit good potential for antioxidant activity at higher concentrations. Figures 8 and 9 show the TAA and DPPH radical scavenging potential of the extracts along with ascorbic acid as reference.

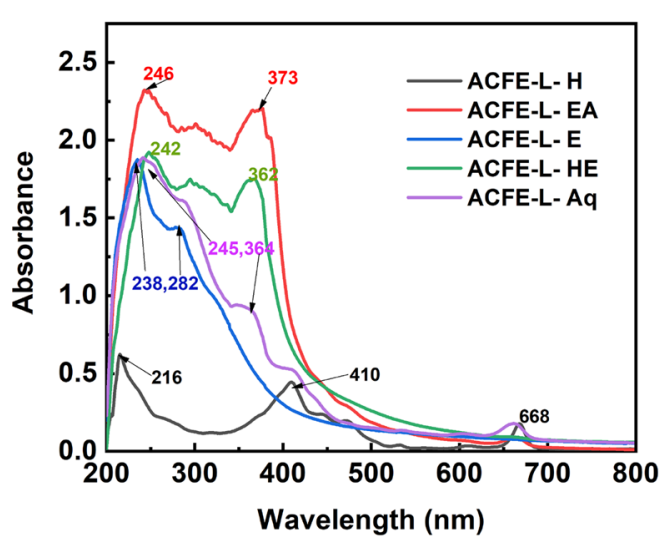

(a)

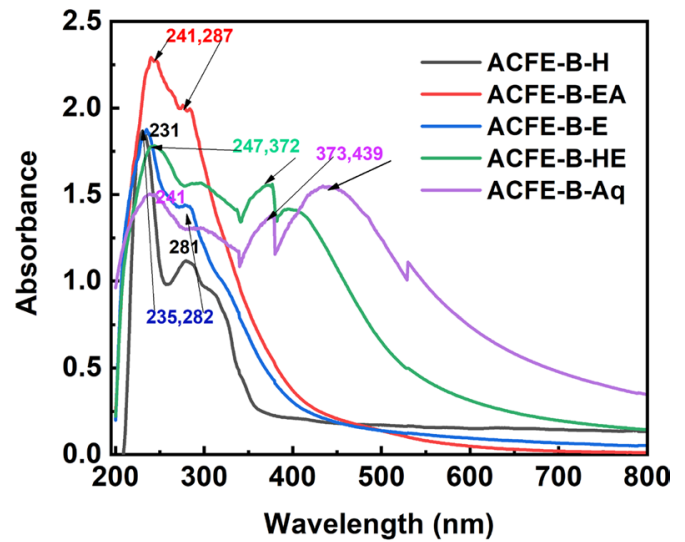

(b)

Fig. 2 a UV-Vis spectrum of A. ferruginea leaf extracts (ACFE-L-H, ACFE-L-EA, ACFE-L-E, ACFE-L-HE, ACFE-L-Aq), b UV-Vis spectrum of A. ferruginea bark extracts (ACFE-B-H, ACFE-B-EA, ACFE-B-E, ACFE-B-HE, ACFE-B-Aq) 


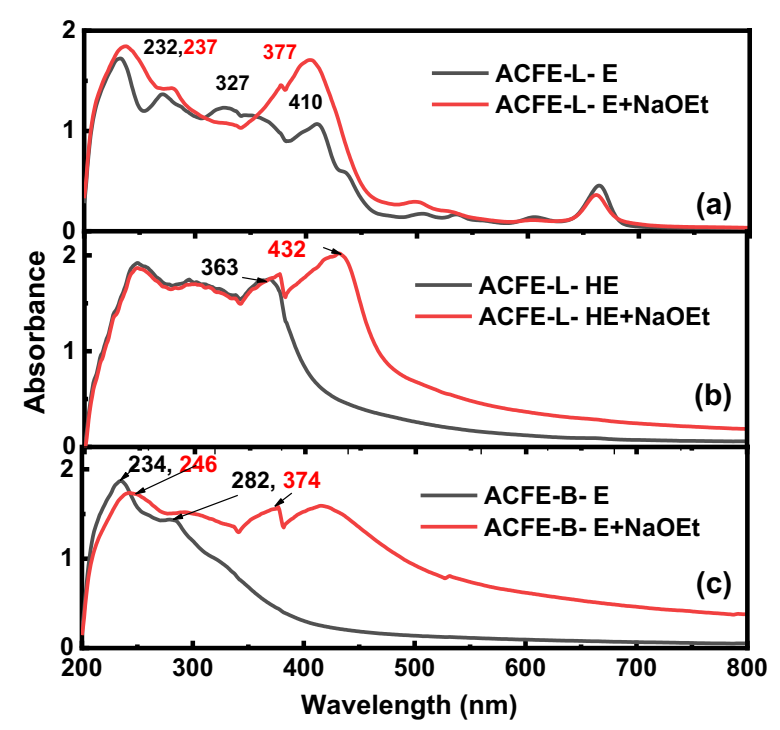

Fig. 3 UV-Vis spectrum of A. ferruginea extracts (concentration: $1 \mathrm{mg} / \mathrm{mL}$ ) before and after adding shift reagent ( $\mathrm{NaOEt}$ ) a mild shift in ACFE-L-E, b redshift from 363 to $432 \mathrm{~nm}$ (absorption maxima) in ACFE-L-HE, c longer wavelength shift in ACFE-B-E

The percent DPPH scavenging activity of the leaf extracts ranged from 5 to $0.74 \%$ and bark from 14 to $78 \%$ at the concentration range of $25-200 \mu \mathrm{g} / \mathrm{mL}$. A significant correlation exists between total antioxidant activity and DPPH - scavenging activity, and the results are comparable.

\section{Discussion}

Herbal plants were originally researched due to their broad medicinal values since the classical era especially Acacia species are utilized to cure a range of illnesses due to their high antioxidant activity. Water is an all-purpose solvent that is often used to extract plant materials. Many conventional healers extract plants mainly with water, although most plant extracts in organic solvents have been found to have more consistent therapeutic properties than water [42]. A. ferruginea bark ethanol extract (ACFE-B-E) has the highest solubility of phytochemicals when extracted with alcohol than the other extracts tested. Trishala and Lakshmi [43] report the same kind of study that $A$. catechu bark ethanol extract showed $2.436 \%$ extractive value which is similar to that of $A$. ferruginea (2.54\%). The difference in extract yields is probably attributed to the different solvent polarities used, which also aids in improving phytochemical component solubility [44].

The term "organoleptic test" refers to observing properties of components that sense organs can use. It thus determines some of the material's unique features, which can be called a first step in determining the material's character and degree of purity. Results reveal that the hexane extract from bark appears as a buff-colored coarse powder with a fragrant odor, and the alcoholic extracts of leaves are of intense odor with a waxy/oily appearance which is listed in Additional file 1: SI-T1. One of the methods for determining the quantity and quality of minerals present in plants is ash content (i.e., total ash, acid-insoluble, and water-soluble ash) and moisture determination, in which the humidity levels in medicinal plants do not reach the recommended level (17\%) [45, 46].

Dry matter is higher in leaves $(95.8 \%)$ than in the bark. The moisture content of the bark sample is $7.61 \%$ and is under the recommended level. Low moisture indicates that the substance would be more resistant to degradation [28]. The results are in agreement with $A$. ferruginea bark extracts (acid-insoluble ash 1.13; water-soluble ash 2.59; water-soluble extractive 11.73; ethanol-soluble extractive 16.57; moisture content 10.2) [47]. The watersoluble and alcohol-soluble extractive values of $A$. ferruginea leaves are higher (91.6 and 97.9\% increase, respectively) than those of the bark.

Solubility tests show the soluble efficacy of extracts in polar and non-polar solvents. Ethanol extract of the bark is soluble in polar solvents and hexane. Both the hexane extracts (bark and leaves) are completely soluble in chloroform, while the aqueous extract has a little miscibility in ethanol. This shift tends to be due to a variation in the polarity of components present in the extracts and the solvents used, which also plays a role in increasing phytochemical compound solubility. Therefore, this result confirms the richness of this plant in polar substances. The dielectric constant, chemical composition of organic solvents, and chemical properties of plant phytochemicals may all influence phytochemical recovery [44].

Fluorescence is a phenomenon that numerous chemical components in plant material exhibit. Many natural chemicals (such as alkaloids like berberine) do not glow in daylight, but under ultraviolet light they emit fluorescence. If the chemicals are not fluorescent by nature, other reagents can typically be used to transform them into fluorescent derivatives or breakdown products. As a result, several crude drugs are frequently evaluated qualitatively, which is an essential pharmacognostic indicator [48]. The bark powder remained colorless with several solvents, but the leaf powder turns a brilliant green color with $\mathrm{FeCl}_{3}$, (under UV light) which might be due to the presence of phenolic rings $(-\mathrm{OH})$. In treatment with various chemical reagents under UV and visible light, both the leaf and bark powder displayed distinctive coloration, notably pale green, pale brown, and black. A nondestructive technique, EDS, can be used to identify trace 


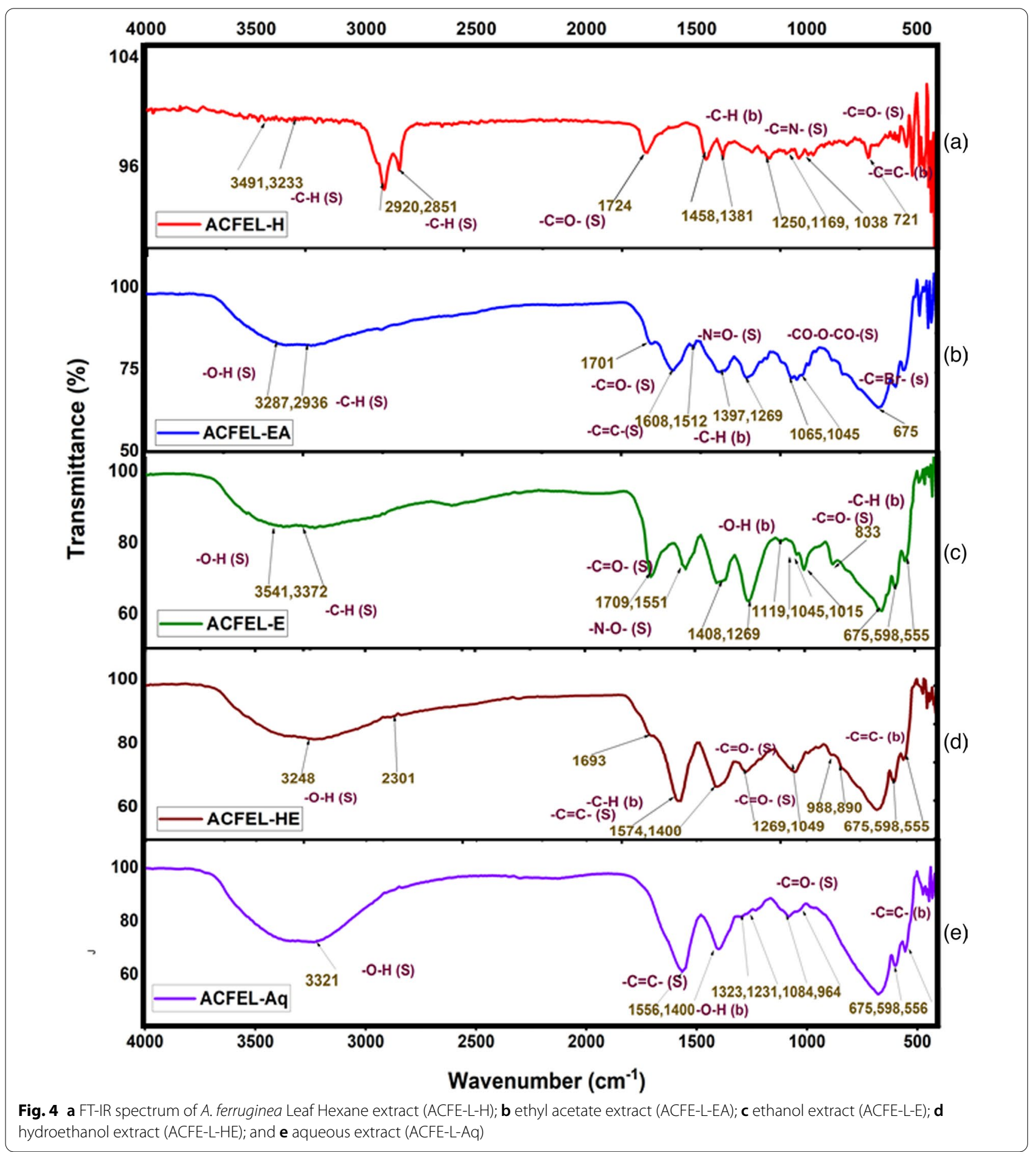

elements, crystals, and multiple sampling in different plant areas, both of which provide data from a nanometer-sized region. Zinc is an important micronutrient as it promotes certain metabolic reactions in plants [49]. A high percentage of zinc (10.64\%) is shown in the leafpolar extracts.
The discovery of phytochemicals may be used to predict the pharmacological operation of plants by calculating various methods, but qualitative assessments like preliminary phytochemical studies are still widely used. The most common chemicals isolated from the Acacia genus are flavonoids, terpenoids, and phenolic 


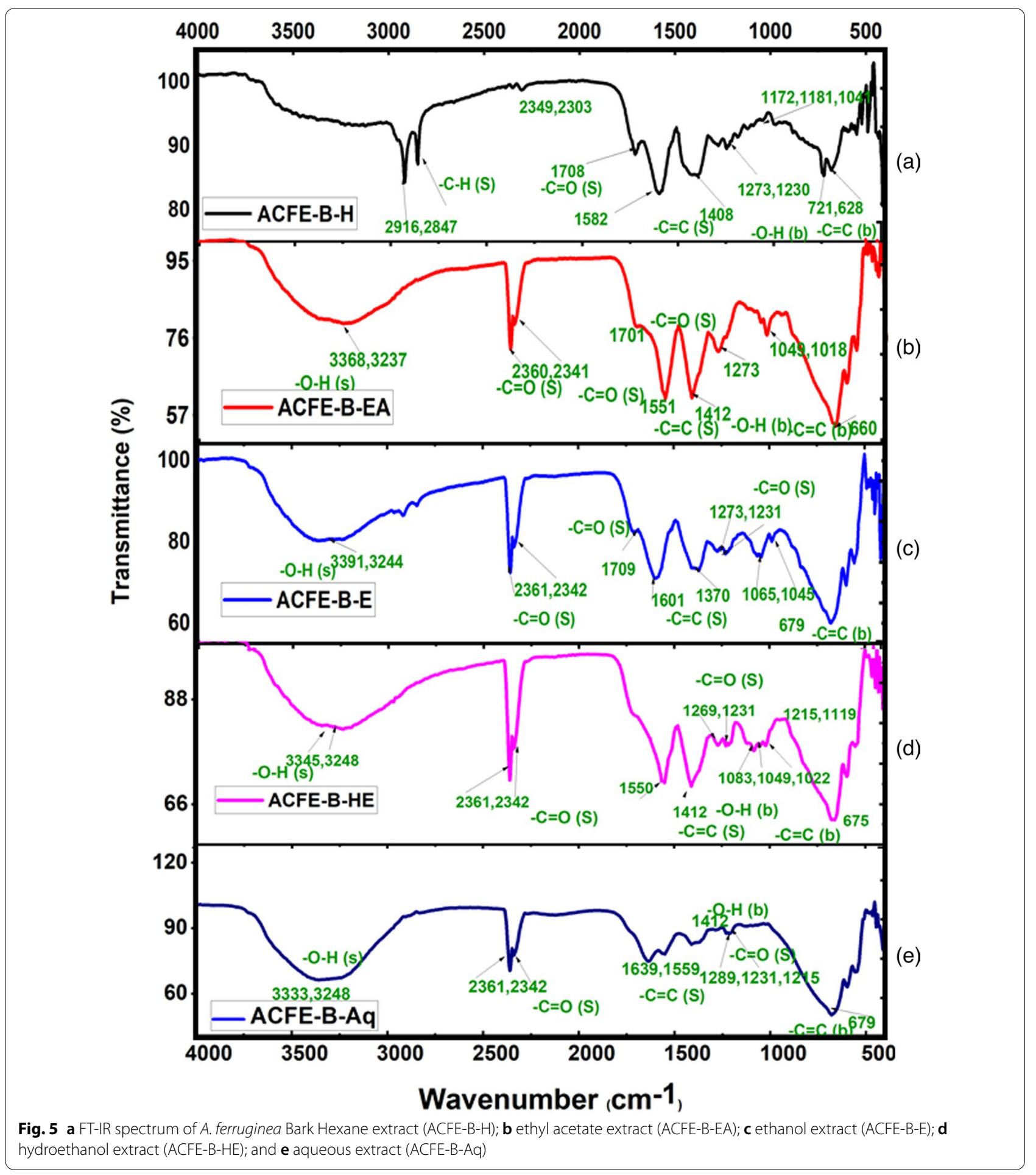

acids [50, 51]. Previous studies have reported that $A$. ferruginea contains alkaloids, steroids, triterpenoids, saponins, flavonoids, tannins, phenolic compounds, carbohydrates, gums, mucilages, proteins, and amino acids [20-23, 52]. The UV-Vis spectra can offer information about compounds with conjugated double bonds of the active components [53]. When the phenolic structure/ triterpenoids are present in molecules, the longer wavelength band experiences a bathochromic shift when an alkali is added [54, 55]. On adding shift reagent (NaOEt), 

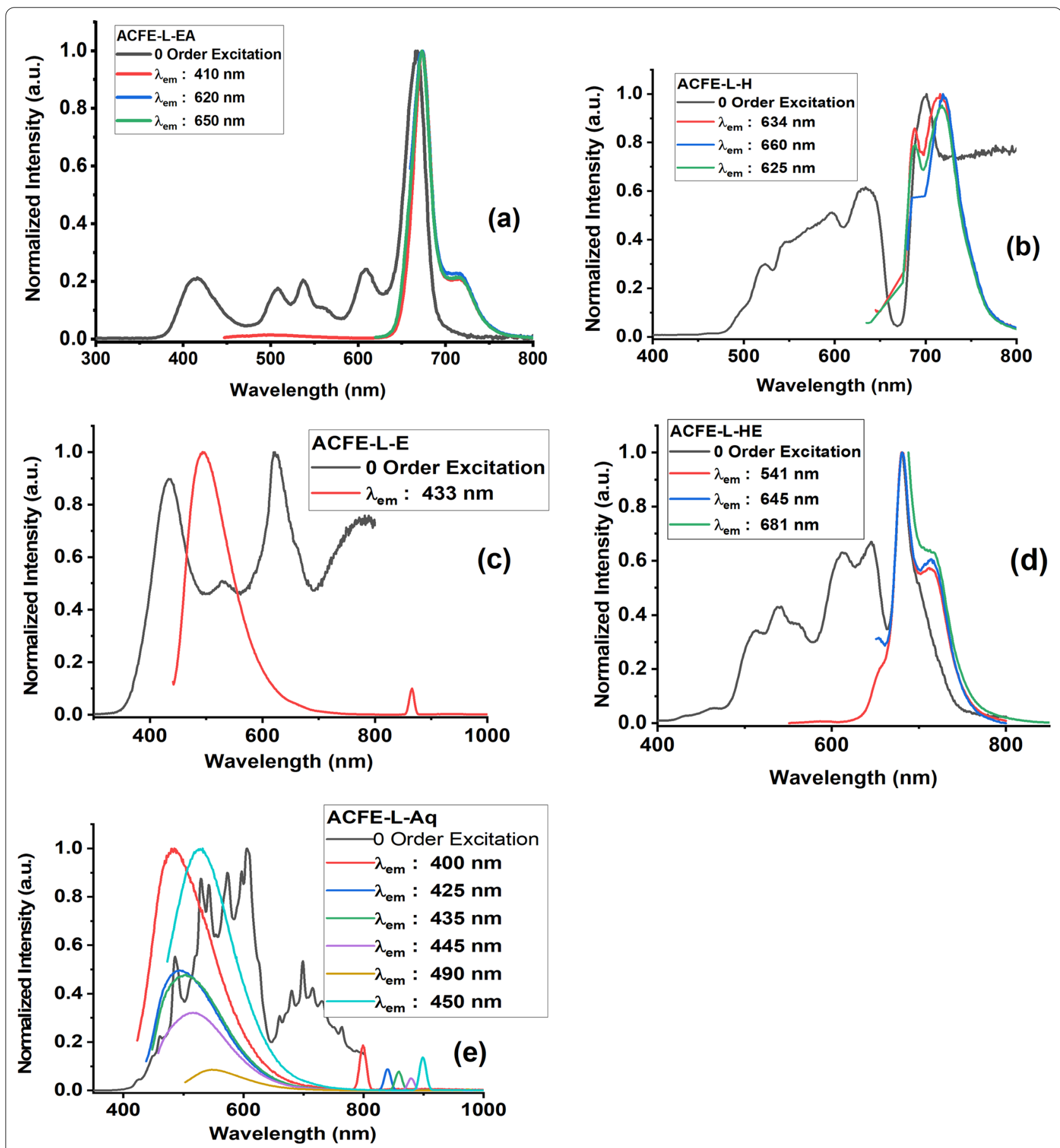

Fig. 6 a Fluorescence spectroscopic profile of A. ferruginea Leaf Hexane extract (ACFE-L-H); b ethyl acetate extract (ACFE-L-EA); c ethanol extract (ACFE-L-E); $\mathbf{d}$ hydroethanol extract (ACFE-L-HE); and e aqueous extract (ACFE-L-Aq)

wavelength shifts are observed for the polar extracts of both bark (235 to $246 \mathrm{~nm}$ ) and leaves ( $232 \mathrm{~nm}$ to $237 \mathrm{~nm}$ ). Surprisingly, the shift is greater (282 to $374 \mathrm{~nm}$ ) in the bark, which may be attributed to the presence of phenolic/triterpenoid compounds.
Fourier-transform infrared spectroscopy (FT-IR) is a high-resolution analytical tool to identify the chemical constituents and elucidate the structural compounds, which offers a rapid and nondestructive investigation to fingerprint herbal extracts or powders [56]. There is no 

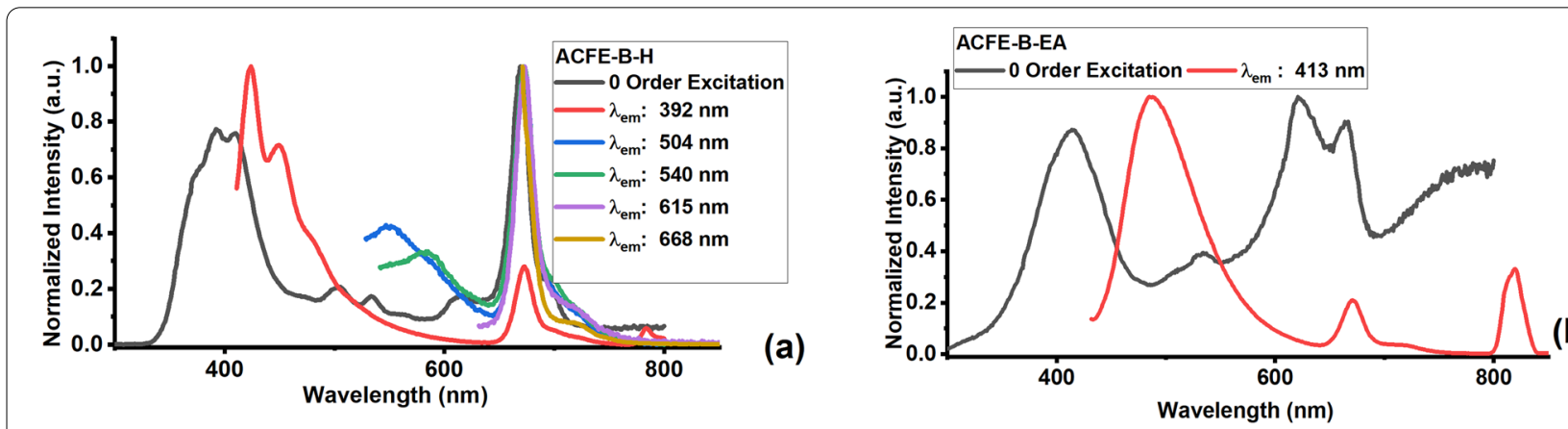

(b)
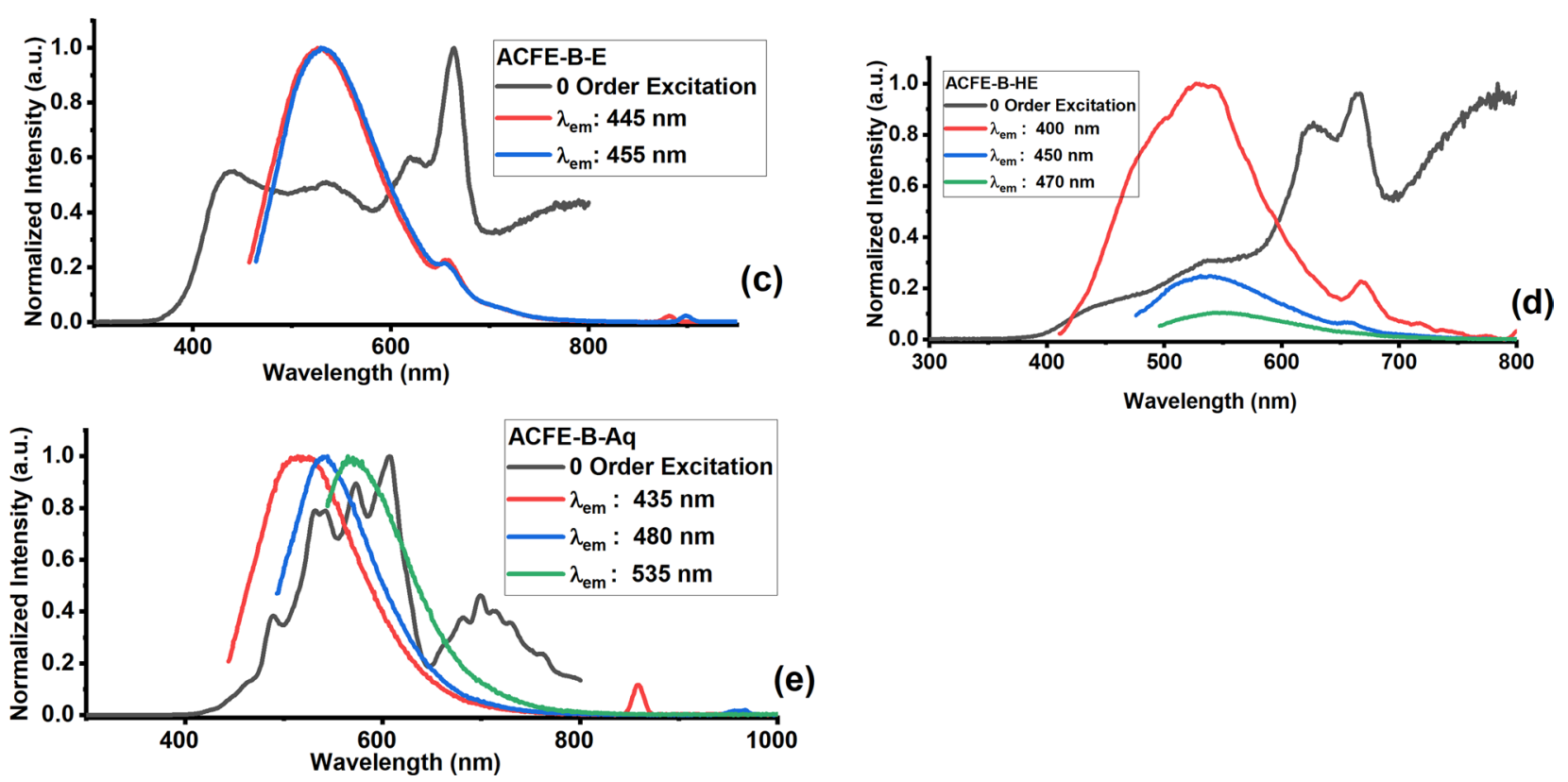

Fig. 7 a Fluorescence spectroscopic profile of A. ferruginea Bark Hexane extract (ACFE-B-H); b ethyl acetate extract (ACFE-B-EA); c ethanol extract (ACFE-B-E); d hydroethanol extract (ACFE-B-HE); and e aqueous extract (ACFE-B-Aq)

peak observed between the region 2220and $2260 \mathrm{~cm}^{-1}$, which indicates the absence of the cyanide group in the extract. This result shows that $A$. ferruginea does not contain any toxic substances. There may be the presence of saponins in A. ferruginea extracts since it has characteristic triterpenoid saponin peaks of $\mathrm{OH}, \mathrm{C}=\mathrm{O}, \mathrm{C}-\mathrm{H}$, and $\mathrm{C}=\mathrm{C}$ [57]. The FT-IR spectrum confirmed the presence of alcohols, phenols, alkanes, alkynes, alkyl halides, aldehydes, aromatics, nitro compounds, and amines. The non-polar extract of ACFE-L-H and ACFE-B-H shows the predominant presence of aliphatic moieties with peaks at 2920, $2851 \mathrm{~cm}^{-1}$, and 2916, $2847 \mathrm{~cm}^{-1}$, respectively, which are absent in polar extract. This assumes the complete separation of non-polar constituents from polar constituents.

Fluorescence spectroscopy is a promising diagnostic method that can be used in plants to track physiological conditions, quality, phytochemicals, nutrient/ environmental pressures, and diseases due to its higher sensitivity and specificity $[58,59]$. In the fluorescence spectra, it can be seen that the fluorescence emission peak for ACFE-B-H and ACFE-B-EA is 489 and $424 \mathrm{~nm}$ when excited at 392 and $413 \mathrm{~nm}$, respectively. Similar results are reported by Atta et al. [59], for p-coumaric acid (370-420 nm). When the samples (ACFE-L-Aq) are excited from 400 to $490 \mathrm{~nm}$ by an increment of 5-15 nm, the resultant fluorescence emission peak continuously redshifted from 482 to $549 \mathrm{~nm}$. Beyond this excitation wavelength, the emission intensity gradually decreases [60]. All the bark extracts show a redshift with variation in intensities except hexane extract. Bands at 400-600 nm represent many leaf fluorophores and secondary metabolites; specifically, chlorogenic acid, ferulic acid, sinapic acid, tannins, carotenoids, flavonoid/flavin, chlorophyll, and anthocyanins $(448 \mathrm{~nm}, 465 \mathrm{~nm}, 436 \mathrm{~nm}$, $506 \mathrm{~nm}, 532 \mathrm{~nm}, 522 \mathrm{~nm}, 680-730 \mathrm{~nm}, 560 \mathrm{~nm}$ ) [60]. The excitation wavelength for ACFE-L-H extract is 634 and 


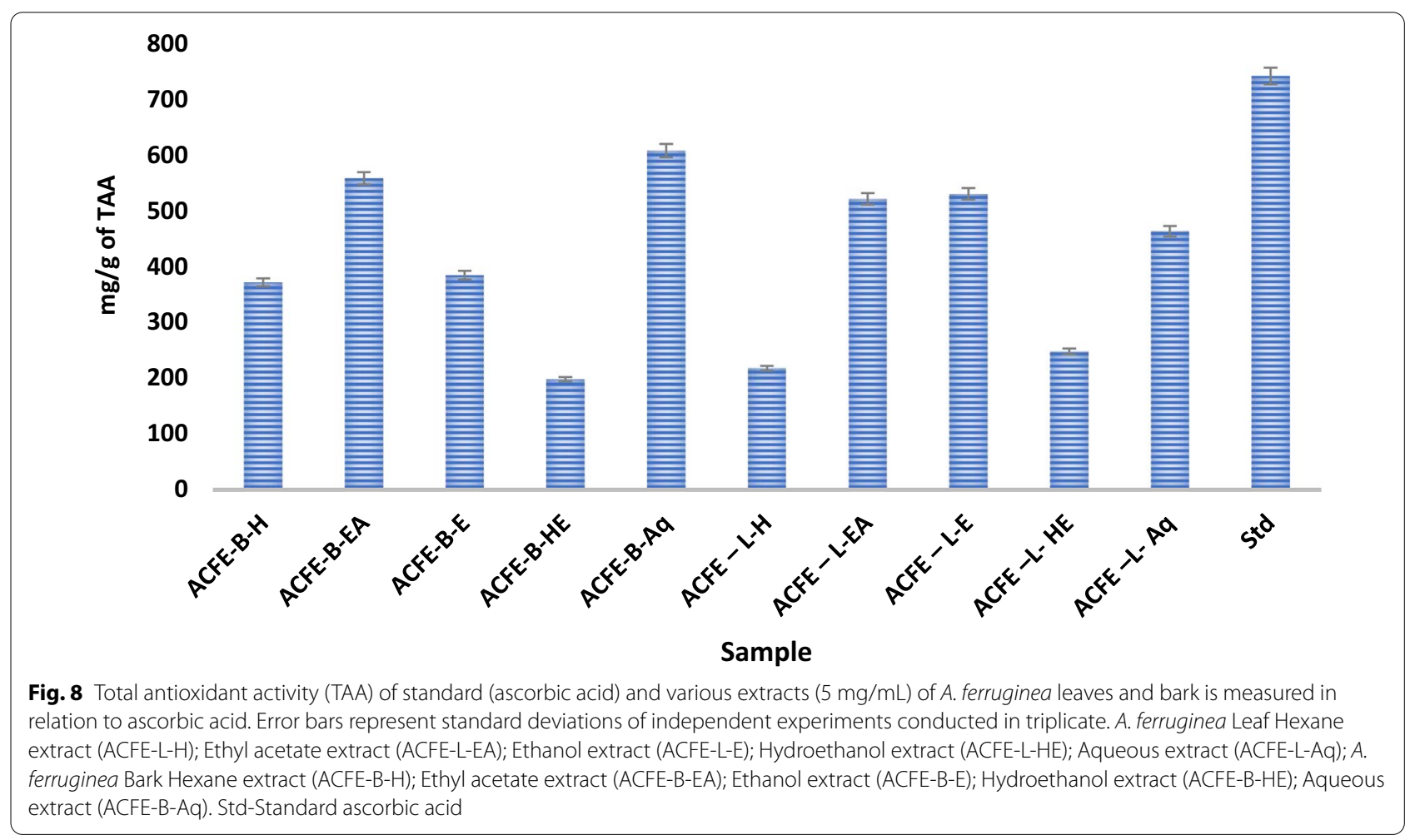

$660 \mathrm{~nm}$. Two distinct maxima, one at 689 and $714 \mathrm{~nm}$ for excitation at $634 \mathrm{~nm}$ and $688,722 \mathrm{~nm}$, are observed for $660 \mathrm{~nm}$ excitation. Since the quantity of extractives present in hexane extract is very small, these two maximal observed may correspond to cellulose/lignin, respectively

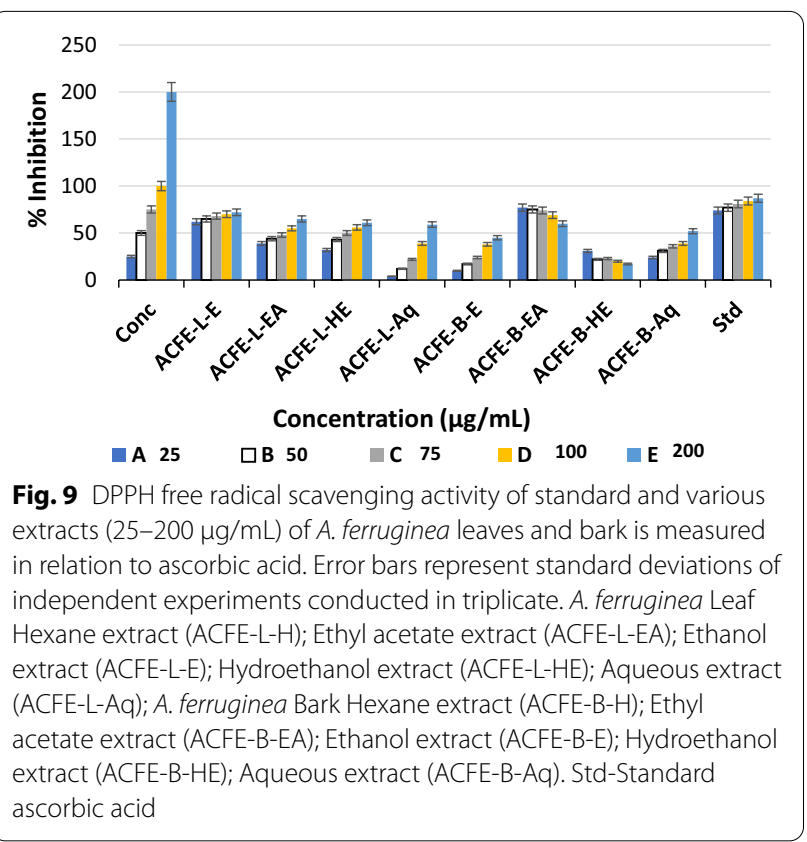

[61]. Spectra measured for leaf extracts are identical to those obtained from the bark and are independent of excitation wavelength. A strong emission peak at $673 \mathrm{~nm}$ is observed for ACFE-L-EA extract when excited at 420, $620,650 \mathrm{~nm}$ and is excitation independent. Both the bark and leaf aqueous extracts were dependent on the excitation wavelength, suggesting the existence of many fluorophores. A new emission peak for ACFE-B-H is observed at 424 and $448 \mathrm{~nm}$ when excited by $392 \mathrm{~nm}$. Most of the extracts except ACFE-B-Aq and ACFE-L-Aq are independent of excitation wavelength, whereas the extracts that exhibit excitation wavelength dependence indicate the presence of many fluorescent chemicals. The need for the systematic study of the plant extracts in different polar and non-polar solvents would be useful for identifying Acacia species. Antioxidants work through various methods, including chain termination by scavenging active species, quenching metal ions, decreasing hydroperoxide and $\mathrm{H}_{2} \mathrm{O}_{2}$ generation, cell death, and cleansing [62]. The extracts of $A$. ferruginea are also used to determine their antioxidant capacities by forming a green phosphomolybdenum complex. The phosphomolybdenum method is based on the reduction of Mo (VI) to $\mathrm{Mo}(\mathrm{V})$ by the antioxidant compound and the formation of a green phosphate/Mo (V) complex with maximal absorption at $695 \mathrm{~nm}$. The antioxidant property of acetone extracts from the tested Acacia species is higher 
and comparable, which may be explained by the fact that the movement of electrons/hydrogen from antioxidants occurs at different redox potentials in different assay systems, and the transfer is also dependent on the composition of the antioxidants [11].

$\mathrm{DPPH} \bullet$ radical scavenging activity has been widely used to evaluate the antioxidant activity of plant extracts and foods [63]. Sowndharrajan et al. [12] also reported that the acetone extract from the stem bark of Acacia species effectively inhibited $\mathrm{H}_{2} \mathrm{O}_{2}$-mediated oxidative stress and may be a useful source as a therapeutic agent to prevent oxidative stress-mediated disorders and diseases. The strong DPPH scavenging activity of A. ferruginea bark suggests that the leaves contain more phenolics that may be attributed to the antioxidant properties of Acacia species [11]. Total antioxidant ability and DPPH radical scavenging activity are all positively associated with saponins and flavonoids [10]. The reducing activity is correlated with aqueous/alcohol-soluble substances due to the presence of bioactive functional groups such as hydroxyl and carbonyl, which lead to reduced or inhibited oxidation [56].

\section{Conclusions}

The findings of the analysis suggest that the leaves and bark of Acacia ferruginea contain a wide variety of phytochemical compounds and higher phenolic content values. Physicochemical characterization studies may be a significant source of information to assess the purity and quality of this plant. Many studies including spectrometric studies and fluorescence studies are reported for the first time in the current work. Additionally, this is used as a diagnostic tool for the standardization of this medicinal plant and is helpful in the characterization of the crude drug. This study demonstrates in an unprecedented way that the crude extract of $A$. ferruginea leaves and bark is rich in pharmaceutically important phytochemicals like alkaloids, saponins, terpenoids, tannins, phenolic compounds, and flavonoids and can neutralize different sources of ROS and presents low toxicity. Thus, it is suggested that there is a synergism between the chemical composition of the extract, especially phenolic compounds, with the high antioxidant capacity demonstrated through different analysis techniques. To recapitulate, it is suggested that the $A$. ferruginea leaf and bark might be a potential source of useful bioactive molecules. It can be concluded that the species is effective in scavenging free radicals and has the potential to be a powerful antioxidant. Therefore, our results open the way for the possible development of natural antioxidants after further studies for the isolation of compounds and more specific investigations to elucidate the mechanisms of action of the extract. Further studies will focus on the isolation and characterization of the possible novel drugs present in this medicinal plant.

\section{Abbreviations}

ACFE-L-H: A. ferruginea Leaf Hexane Extract; ACFE-L-EA: A. ferruginea Leaf Ethyl acetate Extract; ACFE-L-E: A. ferruginea Leaf Ethanol Extract; ACFE-L-HE: A. ferruginea Leaf Hydroethanol Extract; ACFE-L-Aq: A. ferruginea Leaf Aqueous Extract; ACFE-B-H: A. ferruginea Bark Hexane Extract; ACFE-B-EA: A. ferruginea Bark Ethyl acetate Extract; ACFE-B-E: A. ferruginea Bark Ethanol Extract; ACFEL-HE: A. ferruginea Bark Hydroethanol Extract; ACFE-L-Aq: A. ferruginea Bark Aqueous Extract.

\section{Supplementary Information}

The online version contains supplementary material available at https://doi. org/10.1186/s43094-021-00375-4.

Additional file 1.. Materials and methodsSI-M1: 1. Organoleptic properties, 2. Solubility, 3. Determination of $\mathrm{pH}, 4$. Total ash, 4.1. Determination of acid- insoluble ash, 4.2. Determination of water-soluble ash, 4.3. Determination of dry matter, 4.4. Moisture content by loss on drying (LOD) method, 4.5. Determination of foreign matter, 4.6. Water soluble and alcohol soluble extractive values4.7. Fluorescence analysis SI-M2: 1. Qualitative phytochemical studies, 1.1. Analysis of Alkaloids (Hager's Test), 1.2. Analysis of Flavonoids (Test with $\mathrm{NaOH}$, Shinoda Test), 1.3. Analysis of Tannins, 1.4. Analysis of Carbohydrates (Molisch's Test), 1.5. Analysis of Terpenoid (Salkowski Test, Libermann-Buchard Test), 1.6. Analysis of Phenolic Compounds (Ferric Chloride Test, Lead Acetate Test), 1.7. Analysis of Steroids (Libermann-Buchard Test, Test with Concentrated Sulphuric acid), 1.8. Analysis of Saponins (Foam Test). SI-T1: Organoleptic Evaluation of A. ferruginea Bark and Leaf Extracts, SI-T2: Results of Solubility Test of Bark and Leaf Extracts of A. ferruginea, SI-T3: Fluorescence Analysis of A. ferruginea Bark, SI-T4: Fluorescence Analysis of A. ferruginea Leaves, SI-T5: UV Absorption Spectrum Values of A. ferruginea Bark and Leaf extracts, SI-T6: Table of Characteristic IR Absorptions of A. ferruginea Leaf Extracts, SI- T7: Table of Characteristic IR Absorptions of A. ferruginea Bark Extracts, SI-T8: Fluorescence Spectroscopic Profile of A. ferruginea Leaves and Bark Extracts.

\section{Acknowledgements}

The authors are grateful for the support from Avinashilingam Institute for Home Science and Higher Education for Women, Coimbatore-641 043, Tamil Nadu, India, and Sri Ramakrishna Engineering College, Coimbatore-641 022, Tamil Nadu, India, and for the facilities.

\section{Studies involving plants}

1. The leaves and bark parts of the plant material (BSI/SRC/5/23/2018/ Tech/2080) were authenticated by the Botanical Survey of India, Coimbatore. 2. As per the local and national guidelines and legislation and the required or appropriate permissions and/or licenses for the study.

\section{Authors' contributions}

JM designed, analyzed the data, and wrote the manuscript. PVR and SV contributed to data interpretation, editing, formatting, and graphical work. SKS and MP were associated in supervising, advising, and structuring the study and the manuscript. All authors read and approved the final manuscript.

\section{Funding}

$M$ Jeevitha acknowledges funding received from the Department of Science and Technology, under the WOS-A scheme for the study (SR/ WOS-A/CS-25/2018), and Pavithra V Ravi thanks CSIR file number (08/757(0002)/20EMR-I) for Senior Research Fellowship. The funders had no role in the study design, experimental work, or manuscript preparation.

\section{Availability of data and materials}

All data generated or analyzed during this study are included in this published article [and its Additional file 1] and can be accessed/shared with the public. 


\section{Declarations}

Ethics approval and consent to participate

Not applicable.

\section{Consent for publication}

Not applicable.

\section{Competing interests}

The authors declare that they have no competing interests.

\section{Author details}

${ }^{1}$ Department of Chemistry, Avinashilingam Institute for Home Science and Higher Education for Women, Tamil Nadu, Coimbatore 641 043, India. ${ }^{2}$ Department of Nanoscience and Technology, Sri Ramakrishna Engineering College, Tamil Nadu, Coimbatore 641 022, India.

\section{Received: 15 July 2021 Accepted: 26 October 2021}

Published online: 13 November 2021

\section{References}

1. Singh R (2015) Medicinal plants: a review. J Plant Sci 3:50-55. https://doi. org/10.11648/j.jps.s.2015030101.18

2. Sivanandham V (2015) Phytochemical techniques - a review. World J Sci Res 1:80-91

3. Petrovska BB (2012) Historical review of medicinal plants usage. Pharmacogn Rev 6:1-5. https://doi.org/10.4103/0973-7847.95849

4. Mosihuzzaman M, Choudhary MI (2008) Protocols on safety, efficacy, standardization, and documentation of herbal medicine (IUPAC technical report). Pure Appl Chem 80:2195-2230. https://doi.org/10.1351/pac20 0880102195

5. Pandey A, Tripathi S, Pandey CA (2014) Concept of standardization, extraction, and pre phytochemical screening strategies for herbal drug. J Pharmacogn Phytochem JPP 115:115-119

6. Fetrow CW, Avila JR (2004) Professional's handbook of complementary and alternative medicines, 3rd edn. Lippincott Williams \& Wilkins, Philadelphia

7. Upton R, David B, Gafner S, Glas S (2020) Botanical ingredient identification and quality assessment: strengths and limitations of analytical techniques. Phytochem Rev 19:157-1177. https://doi.org/10.1007/ s11101-019-09625-z

8. Sulaiman CT, George S, Gopalakrishnan VK, Balachandran I (2012) Liquid chromatography-electrospray ionization mass spectroscopic analysis of Acacia species. Med Plants 4:226-230. https://doi.org/10.5958/j.09754261.4.4.030

9. Madjid OA, Sanni A, Lagnika L (2020) Chemical diversity and pharmacological properties of genus acacia. Asian J Appl Sci 13:40-59. https://doi. org/10.3923/ajaps.2020.40.59

10. Abdel-Farid IB, Sheded MG, Mohamed EA (2014) Metabolomic profiling and antioxidant activity of some Acacia species. Saudi J Biol Sci 21:400-408. https://doi.org/10.1016/j.sjbs.2014.03.005

11. Sowndhararajan K and Sun C (2013) Protective Effect of ethyl acetate fraction of acacia Ferruginea DC. Against Ethanol-Induced Gastric Ulcer in Rats. J Ethnopharmacol 148(1):175-181

12. Sowndhararajan K, Hong S, Jhoo JW, Kim S, Chin NL (2015) Effect of acetone extract from the stem bark of Acacia species (A. dealbata, A. ferruginea, and $A$. leucophloea) on antioxidant enzymes status in hydrogen peroxide-induced HepG2 cells. Saudi J Biol Sci 22:685-691. https://doi. org/10.1016/j.sjbs.2015.03.010

13. Sakthivel KM, Guruvayoorappan C (2015) Acacia ferruginea inhibits cyclophosphamide-induced immunosuppression and urotoxicity by modulating cytokines in mice. J Immunotoxicol 12:154-163. https://doi org/10.3109/1547691X.2014.914988

14. Kirtikar KR, Basu BD (2003) Indian medicinal plants, 2nd ed., Deharadun, Oriental Enterprises, 1001-1002

15. Maslin BR, Miller JT, Seigler DS (2003) Overview of the generic status of Acacia (Leguminosae: Mimosoideae). Aust Syst Bot 16:1-18. https://doi. org/10.1071/SB02008
16. Ho ST, Tung YT, Chen YL, Zhao YY, Chung MJ, Wu JH (2012) Antioxidant activities and phytochemical study of leaf extracts from 18 indigenous tree species in Taiwan. Evidence-based complementary and alternative medicine. Evid Based Complement Altern Med 2012: 1-8. doi:https://doi. org/10.1155/2012/215959

17. Isaacs J (1987) Bush food: aboriginal food and herbal medicine, Weldons, McMahons Point, NSW

18. Seigler DS (2002) Economic potential from Western Australian Acacia species: secondary plant products. Conserv Sci West Aust 4:109-116

19. Loganayaki N, Siddhuraju P, Manian S (2011) Estudio comparativo de la actividad antioxidante in vitro de las legumbres Acacia auriculiformis y Acacia ferruginea con la legumbre convencional Cajanus cajan. CYTA - J Food 9:8-16. https://doi.org/10.1080/19476330903484216

20. Deb J, Singh A, Rathore DS, Dash GK, Deb NK (2015) Studies on antidiabetic activity of Acacia ferruginea DC. Stem bark. Indian J Pharm Biol.Res 3: 9267. https://doi.org/10.30750/ijpbr.3.4.3

21. Faujdar S, Sharma S, Sati B, Pathak AK, Paliwal SK (2016) Comparative analysis of analgesic and anti-inflammatory activity of bark and leaves of Acacia ferruginea DC. Beni-Suef Univ J Basic Appl Sci 5:70-78. https://doi. org/10.1016/j.bjbas.2016.02.002

22. Sakthivel KM, Guruvayoorappan C (2018) Targeted inhibition of tumor survival, metastasis, and angiogenesis by Acacia ferruginea mediated regulation of VEGF, inflammatory mediators, cytokine profile and inhibition of transcription factor activation. Regul Toxicol Pharmacol 95:400-411. https://doi.org/10.1016/j.yrtph.2018.04.012

23. Faujdar S, Sati B, Sharma S, Pathak AK, Paliwal SK (2019) Phytochemical evaluation and anti-hemorrhoidal activity of bark of Acacia ferruginea DC. J Tradit Complement Med 9:85-89. https://doi.org/10.1016/j.jtcme.2018. 02.003

24. Agarwal P, Goyal A (2021) A comprehensive review on adulteration and substitution of crude drugs. Asian J Pharm Clin Res 14: 33-38. https://doi. org/10.22159/ajpcr.2021.v14i4.40452

25. Ragavendran PC Arul RC, Sophia D, Starlin T, Gopalakrishnan VK (2012) Elemental analysis of Aerva lanata (I.) By EDX method. Int Res J Pharm 3:218-220

26. Giri L, Harish C, Purohit VK, Rawat MSM, Rawal RS, Bhatt ID (2010) Chromatographic and spectral fingerprinting standardization of traditional medicines: an overview as modern tools. Res J Phytochem 4:234-241. https://doi.org/10.3923/rjphyto.2010.234.241

27. Chikezie PC, Ekeanyanwu RC, Chile-Agada AB (2020) Phytocomponents from Anacardium occidentale, Psidium guajava, and Terminalia catappa altered membrane osmotic stability of sickle erythrocytes. Beni-Suef Univ J Basic Appl Sci 9:1-22. https://doi.org/10.1186/s43088-019-0030-z

28. Kulkarni K, Jagtap G, Magdum S (2019) A comprehensive review on herbal drug standardization. Am. J. PharmTech Res 9: 97-122. https://doi. org/10.46624/ajptr.2019.v9.i3.007

29. Okoli BJ, Modise JS (2017) New pharmacophore from the stem bark fractions of acacia decurrens (Willd), an invasive South Africa tree. J Appl Chem. https://doi.org/10.1155/2017/1815278

30. Divya KM, Rubeena M, Sunil Kumar KN, Parameswaran S (2018) IUCN red listed medicinal plants of siddha. J Res Sid Med 1:15-22

31. Littorale E, Sanmugarajah V, Thabrew I, Sivapalan SR (2013) Phyto, physicochemical standardization of medicinal plant. IOSR J Pharm 3:52-58

32. Thiex N, Novotny L, Crawford A (2012) Determination of ash in animal feed: AOAC official method 942.05. J AOAC Int 95:1392-1397. https://doi. org/10.5740/jaoacint.12-129

33. The Indian Pharmacopoeia (1996) The controller of publication, Delhi (CSIR) Vol-2, Part II

34. World Health Organization (1999) Herbae centellae, WHO Monogr.Sel. Med. Plants, 77-85

35. The Ayurvedic Pharmacopoeia of India (1999) Part 1, Vol. II, (Govt. of India Ministry of Health and Family Welfare), New Delhi

36. Kokoski CJ, Kokoski RJ, Slama FJ (1958) Fluorescence of powdered vegetable drugs under ultraviolet radiation. J Am Pharm Assoc Am Pharm Assoc (Baltim) 47:715-717. https://doi.org/10.1002/jps.3030471010

37. Pradhan AN, Agrahari AK, Meher A, Mishra MN (2010) Elemental analysis by energy-dispersive $x$-ray spectroscopy (EDX) of Capparis zeylanica Linn. Plant J Pharma Res 3(4):669-670

38. Harborne JB (1973) Phytochemical methods, a guide to modern techniques of plant analysis. Chapman and Hall, London, pp 267-270 
39. Harborne JB (1973). Phytochemical methods. London Chapman and Hall, Ltd, 49-188

40. Sharadanand Phatak R, Subhash Hendre A, Rohan Sharadanand Phatak C (2014) Total antioxidant capacity (TAC) of fresh leaves of Kalanchoe pinnata. J Pharmacogn Phytochem JPP 2:32-35

41. Chaves N, Santiago A, Alías JC (2020) Quantification of the antioxidant activity of plant extracts: analysis of sensitivity and hierarchization based on the method used. Antioxidants 9:1-14. https://doi.org/10.3390/antio x9010076

42. Madane A, Kamble S, Patil BJ, Vishal A (2013) Assessment of solvent solubility by using phytochemical screen test of some Euphorbiaceae members. Asian J Pharm Res 3:53-55

43. Trishala A, Thangavelu A (2018) Physicochemical profile of acacia catechu bark extract: an in vitro study. Int j pharm 8:84-87

44. Felhi S, Daoud A, Hajlaoui H, Mnafgui K, Gharsallah N, Kadri A (2017) Solvent extraction effects on phytochemical constituents profiles, antioxidant and antimicrobial activities and functional group analysis of Ecballium elaterium seeds and peels fruits. Food Sci Technol 37:483-492. https://doi.org/10.1590/1678-457x.23516

45. Saebi A, Minaei S, Mahdavian AR, Ebadi MT (2021) Precision harvesting of medicinal plants: elements and ash content of hyssop (Hyssopus officinalis L.) as affected by harvest height. Biol Trace Elem Res 199:753-762. https://doi.org/10.1007/s12011-020-02171-2

46. Beghlal D, El Bairi K, Marmouzi I, Haddar L, Mohamed B (2016) Phytochemical, organoleptic and ferric reducing properties of essential oil and ethanolic extract from Pistacia lentiscus (L.). Asian Pacific J Trop Dis 6:305-310. https://doi.org/10.1016/S2222-1808(15)61035-0

47. Deb J, Dash GK (2014) Pharmacognostical studies on stem bark of Acacia ferruginea DC. Pharm Lett 6:61-66

48. Chase CR, Pratt R (1949) Fluorescence of powdered vegetable drugs. Indian J Exp Biol 33(6): 428-432

49. Poongothai G, Sripathi SK (2015) Documentation of physiochemical parameters of the folkloric medicinal plant pisonia Grandis R.Br. reared under greenhouse and local environment conditions. Res J Med Plant 9:427-434. https://doi.org/10.3923/rjmp.2015.427.434

50. Shaikh JR, Patil M (2020) Qualitative tests for preliminary phytochemical screening: an overview. Int J Chem Stud 8:603-608. https://doi.org/10. 22271/chemi.2020.v8.i2i.8834

51. Amoussa AMO, Lagnika L, Bourjot M, Vonthron-Senecheau C, Sanni A (2016) Triterpenoids from Acacia ataxacantha DC: antimicrobial and antioxidant activities. BMC Complement Altern Med 16:1-8.https://doi. org/10.1186/s12906-016-1266-y

52. Sowndhararajan K, Santhanam R, Hong S, Jhoo JW, Kim S (2016) Suppressive effects of acetone extract from the stem bark of three Acacia species on nitric oxide production in lipopolysaccharide-stimulated RAW 264.7 macrophage cells. Asian Pac J Trop Biomed 6:658-664. https://doi.org/10. 1016/j.apjtb.2016.06.005

53. Ríos JL, Recio MC, Máñez S, Giner RM (2000) Natural triterpenoids as antiinflammatory agents. Stud Nat Prod Chem 22:93-143. https://doi.org/10. 1016/S1572-5995(00)80024-1

54. Gunatilaka AAL (1996) Triterpenoid quinonemethides and related compounds (Celastroloids). Prog Chem Org Nat Prod. https://doi.org/10.1007/ 978-3-7091-9406-5 1

55. Ku CS, Mun SP (2007) Characterization of proanthocyanidin in hot water extract isolated from Pinus radiata bark. Wood Sci Technol 41:235-247. https://doi.org/10.1007/s00226-006-0103-8

56. Altemimi A, Lakhssassi N, Baharlouei A, Watson DG, Lightfoot DA (2017) Phytochemicals: extraction, isolation, and identification of bioactive compounds from plant extracts. Plants 6(4). doi:https://doi.org/10.3390/ plants6040042

57. Almutairi MS, Ali M (2015) Direct detection of saponins in crude extracts of soapnuts by FTIR. Nat Prod Res 29: 1271-1275.https://doi.org/10.1080/ 14786419.2014 .992345

58. Liang L, He Q (2016) Comparative study on fluorescence spectra of Chinese Medicine North and South Isatis Root Granules. Nat Prod Chem Res 04:4-7. https://doi.org/10.4172/2329-6836.1000201

59. Atta BM, Saleem M, Ali H, Bilal M, Fayyaz M (2020) Application of fluorescence spectroscopy in wheat crop: early disease detection and associated molecular changes. J Fluoresc 30:801-810. https://doi.org/10.1007/ s10895-020-02561-8

60. Su Y, Dong H, Li M, Lai C, Huang C, Yong Q (2019) Isolation of the flavonoid from bamboo residues and its application as metal ion sensor in vitro. Polymers (Basel) 11(9):1377. https://doi.org/10.3390/polym11091 377

61. Ding Q, Han W, Li X, Jiang Y, Zhao C (2020) New insights into the autofluorescence properties of cellulose/nanocellulose. Sci Rep 10:1-8. https:// doi.org/10.1038/s41598-020-78480-2

62. Sen S, Chakraborty R, Sridhar C, Reddy YSR, De B (2010) Free radicals, antioxidants, diseases, and phytomedicines: current status and future prospect. Int J Pharm Sci Rev Res 3:91-100

63. Soares JR, Dinis TCP, Cunha AP, Almeida LM (1997) Antioxidant activities of some extracts of Thymus zygis. Free Radic Res 26:469-478. https://doi. org/10.3109/10715769709084484

\section{Publisher's Note}

Springer Nature remains neutral with regard to jurisdictional claims in published maps and institutional affiliations.

\section{Submit your manuscript to a SpringerOpen ${ }^{\circ}$ journal and benefit from:}

- Convenient online submission

- Rigorous peer review

- Open access: articles freely available online

- High visibility within the field

- Retaining the copyright to your article

Submit your next manuscript at $\boldsymbol{\nabla}$ springeropen.com 